\title{
Treatment of Benign Prostatic Hyperplasia by Occlusion of the Impaired Urogenital Venous System - First Experience
}

\author{
Behandlung der benignen Prostatahyperplasie durch Embolisation \\ des insuffizienten urogenitalen Venensystems - eine Zwischenbilanz
}

Authors

Affiliation
H. Strunk, M. Meier, H. H. Schild, M. Rauch

Department of Radiology, University Bonn, Germany
Key words

- abdomen

prostate

- blood vessels

- genital/reproductive

received 16.4.2014

accepted $\quad 8.9 .2014$

Bibliography

Dol http://dx.doi.org/

10.1055/s-0034-1385353

Published online: 12.11.2014

Fortschr Röntgenstr 2015; 187:

180-186 @ Georg Thieme

Verlag KG Stuttgart · New York . ISSN 1438-9029

\author{
Correspondence \\ Dr. Maximilian Rauch \\ Dep. of Radiology, \\ University Bonn \\ Sigmund-Freud-Str. 25 \\ 53105 Bonn \\ Germany \\ Tel.: ++ 49/2 28/28715091 \\ Fax: ++49/228/28711166 \\ maximilian.rauch@ \\ ukb.uni-bonn.de
}

\section{Abstract \\ $\nabla$}

Purpose: To effect regression of benign prostatic hyperplasia (BPH), Gat et al. (Andrologia 2008 ) proposed to occlude incompetent spermatic veins to reduce increased hydrostatic pressure on the prostatic venous plexus and prevent reflux with androgen rich blood from the testicles. Our aim was to implement this treatment strategy in clinical practice and to report about first results.

Methods: Embolization of the spermatic veins was performed in 30 patients with $\mathrm{BPH}$. In 16 patients, we obtained follow-up data from at least 6 months. The sonographic transabdominal prostatic volume, prostatespecific antigen (PSA) and peripheral total testosterone levels were determined before and 6 months after the intervention. Subjective symptomatology was assessed using standardized questionnaires (International Prostate Symptom Score [IPSS] and Quality of Life score $[\mathrm{QoL}])$ before and 6 months after the procedure.

Results: The age of all treated patients was $46-77$ years. The age of the 16 patients who received follow-up was 51-77 years. IPSS (median 18 [IQR 20.75-14.50] vs. 9 [IQR $11.00-7.25], \mathrm{p}<0.0001)$ and QoL score (4 [IQR 5-3] vs. 2 [IQR 3-1], p<0.001) were significantly decreased 6 months after the intervention. The subjective improvement of symptoms did not correspond with prostatic volumes, which did not change significantly (54.31 \pm 30.90 vs. $50.50 \pm 29.26 \mathrm{ml}, \mathrm{p}=\mathrm{n} . \mathrm{s}$.). $4 / 16$ patients had a measurable post-void urine volume, which decreased in two patients 6 months after the procedure, remained unchanged in one patient, and was no longer detectable in one patient. 4 of the 11 had a sonographically detectable varicocele before the intervention, and one patient had a trabe- culated bladder. Both the peripheral total testosterone levels ( $4.55 \pm 1.27$ vs. $3.93 \pm 1.00 \mathrm{ng} /$ $\mathrm{ml} ; \mathrm{p}=\mathrm{n}$. s.) and PSA levels (3.74 \pm 2.83 vs. $4.06 \pm 3.34 \mathrm{ng} / \mathrm{ml} ; \mathrm{p}=\mathrm{n}$. s.) showed no significant differences.

Conclusion: Interventional occlusion of the spermatic veins in patients with $\mathrm{BPH}$ is a feasible outpatient procedure with a low complication rate. Intermediate results are satisfactory. Mid- and long-term results and pathophysiologic mechanisms need to be further elucidated.

Key Points:

- Venous embolization in patients with BPH is a feasible outpatient procedure.

- It shows satisfactory intermediate result with good symptom relief.

- Medium and long-term results need to be further evaluated.

Citation Format:

- Strunk H, Meier M, Schild HH et al. Treatment of Benign Prostatic Hyperplasia by Occlusion of the Impaired Urogenital Venous System - First Experience. Fortschr Röntgenstr 2015; 187: 180-186

\section{Zusammenfassung}

$\nabla$

Ziel: Nach dem von Gat et al. (Andrologia 2008) vorgeschlagenen Prinzip soll eine Embolisation der insuffizienten Testikularvenen bei Patienten mit benigner Prostatahyperplasie (BPH) einen erhöhten hydrostatischen Druck im prostatischen Venenplexus senken und eine Überflutung der Prostata mit androgenreichem Blut aus dem Hoden verhindern, sodass eine Regression der BPH resultiert. Dieses neue Therapieprinzip sollte im Rahmen der klinischen Routine eingesetzt und über erste Ergebnisse berichtet werden.

Methoden: Bei 30 Patienten mit BPH wurde eine Embolisation der Testikularvenen durchgeführt. 
Bei 16 Patienten lagen zum Stichtag Nachsorgedaten von wenigstens 6 Monaten vor. Sonografisches transabdominelles Prostatavolumen, prostataspezifisches Antigen (PSA) und peripheres Gesamttestosteron wurden vor und 6 Monate nach dem Eingriff bestimmt. Die subjektive Beschwerdesymptomatik wurde mittels internationalem Prostata Symptom Score (IPSS) und Quality of Life Index (QoL) vor und 6 Monate nach dem Eingriff bestimmt. Ergebnisse: Das Patientenalter betrug beim Eingriff 46 - 77 Jahren, das der 16 verlaufskontrollierten Patienten $51-77$ Jahre. IPSS (Median 18 [IQR 20,75-14,50] vs. 9 [IQR 11,00-7,25], $\mathrm{p}<0,0001$ ) und QoL-Score (4 [IQR 5-3] vs. 2 [IQR 3-1], $\mathrm{p}<0,001$ ) waren 6 Monate nach dem Eingriff signifikant erniedrigt. Die subjektive Beschwerdebesserung fand in der Messung des Prostatavolumens kein Korrelat, welches mit 54,31 $\pm 30,90$ vs. $50,50 \pm 29,26 \mathrm{ml}(\mathrm{p}=$ n. s.) nicht signifikant verändert war. Bei 4 der 16 behandelten Patienten ließ sich ein Restharnvolumen nachweisen, welches bei zwei Patienten 6 Monate nach dem Eingriff unverändert, bei einem Patient rückläufig war, bei einem Patient war kein Restharn mehr nachweisbar. Bei 4/16 Patienten war vor dem Eingriff auch sonografisch eine Varikozele nachweisbar, bei einem Patienten eine Balkenblase. Bei den peripheren Gesamttestosteronwerten $(4,55 \pm 1,27$ vs. $3,93 \pm 1,00 \mathrm{ng} / \mathrm{ml}$; $\mathrm{p}=\mathrm{n}$. s.) und den PSA-Werten $(3,74 \pm 2,83$ vs. $4,06 \pm 3,34 \mathrm{ng} / \mathrm{ml}$; $\mathrm{p}=\mathrm{n}$. s.) konnten im Verlauf keine signifikanten Unterschiede festgestellt werden.

Schlussfolgerung: Die venöse Embolisationsbehandlung der BPH ist ein ambulant durchführbarer Eingriff mit geringer Komplikationsrate. Es zeigt sich ein zufriedenstellendes Zwischenergebnis. Mittel- und längerfristige Ergebnisse sowie pathophysiologische Mechanismen des Eingriffs sind weiter zu evaluieren.

\section{Introduction}

$\nabla$

Although testosterone promotes cell proliferation in the prostate [1], a low serum testosterone level is seen in patients with benign prostate hyperplasia (BPH) [2]. Interestingly, it was nonetheless able to be shown that the administration of antiandrogenic medications can have a reductive effect on BPH [3].

Based on this paradox, Gat et al. 2008 formulated the hypothesis that venous valve insufficiency of the spermatic veins may be responsible for the development of $\mathrm{BPH}$ [4]: On the one hand, the valve insufficiency results in reflux via venous collaterals into the prostatic plexus which can cause an increase in the volume of the organ. On the other hand, the backed-up blood contains significant quantities of free, unbound, i.e., active, testosterone. This hormone load causes accelerated cell proliferation and can ultimately lead to prostate hyperplasia.

Occlusion of the insufficient spermatic veins is intended to eliminate the pathological hydrostatic pressure thus correcting the reflux and volume load. As a result of the changed flow conditions, the testosterone-rich blood flows via the vesical veins to the systemic circulation without impacting the prostate. This is intended to reverse the hyperplasia. The goal of our study was to use the vein occlusion treatment concept used by Gat et al. in the clinical routine and to report initial results.

\section{Patients and Methods}

\section{$\nabla$}

The following evaluation was based on 30 consecutive patients treated by intervention for benign prostate hyperplasia (BPH) at our clinic by February 2014. Follow-up data from at least 6 months was available for 16 of these patients by the cut-off date.

The inclusion criteria were an age of $>40$ years, confirmed $\mathrm{BPH}$, no obstructive uropathy, no acute urinary retention, failure of treatment with medication for at least 6 months or rejection of treatment with medication as well as rejection of surgery by the patient. The exclusion criteria were acute urinary retention, obstructive uropathy, confirmed prostate carcinoma and contraindications for intervention, such as coagulation defect, renal insufficiency.

All patients contacted the clinic on their own because they had heard or read about the vein occlusion treatment concept used by Gat et al. [4].

All patients were informed of possible complications, such as contrast medium reactions, infections, bleeding and other vascular complications, orchitis, epididymitis, and possible treatment failure, prior to intervention ( $\bullet$ Table 1 ).

Patients were also informed of other available BPH treatment options during the preoperation discussion. At this time

- The patient history including prior treatments, interventions, secondary diagnoses, and medication history were recorded.

- Ultrasound of both kidneys, the bladder (before and after urination), the prostate (transabdominal), and both testicles (to sonographically detect a varicocele) was performed and documented. The prostate volume was calculated with the ellipsoid formula.

- Patients were asked to complete a standardized questionnaire regarding quality of life [QOL]) and another questionnaire (International Prostate Symptom Score [IPSS]), which were used to classify the severity of the voiding disorder and the associated level of suffering [5] ( Table 2, 3).

- The following laboratory values were determined: PSA, peripheral total testosterone, creatinine, TSH, clotting.

The intervention was performed in $26 / 30$ patients completely via a right cubital vein access (cephalic vein or basilic vein, $5 F$ introducer) and in 1/30 patients via the right femoral vein ( $5 \mathrm{~F}$ introducer) due to the lack of a suitable cubital puncture point. The left spermatic vein was probed most effectively with a $5 \mathrm{~F}$ vertebral catheter and the right spermatic vein with a $5 \mathrm{~F}$ headhunter 1 catheter.

Table 1 Reported complications after varicocele occlusion.

\begin{tabular}{|ll|}
\hline complications & frequency \\
\hline $\begin{array}{l}\text { large hematoma (after accidental arterial puncture) } \\
\begin{array}{l}\text { aneurysmal hematoma (after accidental arterial } \\
\text { puncture) }\end{array}\end{array}$ & $<0.4 \%[6]$ \\
\hline $\begin{array}{l}\text { arteriovenous fistula } \\
\text { contrast agent intolerance with severe anaphylactic } \\
\text { reaction }\end{array}$ & $0.04 \%[8]$ \\
\hline $\begin{array}{l}\text { thrombosis and/or thrombophlebitis of the pampi- } \\
\text { niform plexus }\end{array}$ & $0.5 \%[9]$ \\
\hline \begin{tabular}{l} 
orchitis and/or epididymitis \\
\hline
\end{tabular} & $0-4 \%[6]$
\end{tabular}




\begin{tabular}{|c|c|c|c|c|c|c|}
\hline questionnaire regarding urination & never & $\begin{array}{l}\text { less frequently } \\
\text { than in } 1 \text { of } 5 \\
\text { cases }\end{array}$ & $\begin{array}{l}\text { less frequently } \\
\text { than in half of } \\
\text { all cases }\end{array}$ & $\begin{array}{l}\text { approxima- } \\
\text { tely in half } \\
\text { of all cases }\end{array}$ & $\begin{array}{l}\text { in more } \\
\text { than half of } \\
\text { all cases }\end{array}$ & $\begin{array}{l}\text { almost } \\
\text { always }\end{array}$ \\
\hline $\begin{array}{l}\text { How often in the last month have you had the feeling } \\
\text { that your bladder was not completely empty after } \\
\text { urination? }\end{array}$ & 0 & 1 & 2 & 3 & 4 & 5 \\
\hline $\begin{array}{l}\text { How often in the last month have you had to urinate } \\
\text { a second time in less than two hours? }\end{array}$ & 0 & 1 & 2 & 3 & 4 & 5 \\
\hline $\begin{array}{l}\text { How often in the last month have you had to stop and } \\
\text { start again during urination? }\end{array}$ & 0 & 1 & 2 & 3 & 4 & 5 \\
\hline $\begin{array}{l}\text { How often in the last month have you had difficulty } \\
\text { delaying urination? }\end{array}$ & 0 & 1 & 2 & 3 & 4 & 5 \\
\hline $\begin{array}{l}\text { How often in the last month have you had a weak } \\
\text { stream during urination? }\end{array}$ & 0 & 1 & 2 & 3 & 4 & 5 \\
\hline $\begin{array}{l}\text { How often in the last month have you had to push } \\
\text { or strain to start urinating? }\end{array}$ & 0 & 1 & 2 & 3 & 4 & 5 \\
\hline $\begin{array}{l}\text { On average, how often in the last month have you had } \\
\text { to get up in the night to urinate? The time between } \\
\text { going to bed at night and getting up in the morning is } \\
\text { decisive. }\end{array}$ & 0 & 1 & 2 & 3 & 4 & 5 \\
\hline Total & $\begin{array}{l}0-7 p o \\
8-19 p \\
20-35\end{array}$ & $\begin{array}{l}\text { ts: mild symptom } \\
\text { nts: moderate syr } \\
\text { jints: severe symp }\end{array}$ & oms & & & \\
\hline
\end{tabular}

Table 3 Quality of life score.

\begin{tabular}{|lllllll}
\hline quality of life index & excellent & satisfied & $\begin{array}{l}\text { largely } \\
\text { satisfied }\end{array}$ & $\begin{array}{l}\text { mixed, partly } \\
\text { satisfied, partly } \\
\text { unsatisfied }\end{array}$ & $\begin{array}{l}\text { largely } \\
\text { unsatisfied }\end{array}$ & unhappy \\
\hline $\begin{array}{l}\text { How would you feel if you } \\
\text { could not change your current } \\
\text { symptoms during urination for } \\
\text { the rest of your life? }\end{array}$ & 0 & 1 & 2 & 3 & 4 & 5 \\
\hline
\end{tabular}

In 3/30 patients with cubital access, it was not possible to probe the right spermatic vein due to opening angle into the inferior vena cava. In these cases an additional femoral access was created after initial cubital puncture and was then used to probe the right side via a 5F sidewinder 1 catheter. The catheters were advanced via a guidewire as far as possible in a distal direction to at least under the iliac crest. Contrast medium was injected to visualize the caudal spermatic vein and any vertical collaterals with retrograde contrast enhancement. Since vertical collaterals exert the same hydrostatic pressure as the spermatic veins on the pampiniform plexus, these must also be embolized [4] ( $\bullet$ Fig.1). A foamed mixture of 2 parts polidocanol (Aethoxysklerol, Nycomed) and 3 parts air was slowly injected for treatment. It was ensured that the previously injected contrast medium was forced out of the spermatic vein and collaterals by the sclerosing agent to the greatest extent possible to ensure sufficient occlusion of the vessels.

If a solitary large-caliber spermatic vein was seen, one or two metal coils (Tornado $10-4,6-3,8-4$ or Nester $14-4$, 14-6, 14-8, Cook Medical) were additionally inserted to securely occlude the vessel. The catheter and introducer were then removed, the puncture point was manually compressed for several minutes, and a light compression bandage was applied. Symptom-free patients were discharged after an observation period of one hour for a cubital punc- ture and after six hours in the case of a transfemoral puncture with the condition of returning to the clinic immediately in the case of a recurrence of symptoms.

6 months after the intervention

- The abdominal ultrasound scan of both kidneys, the bladder (before and after urination), the prostate, and both testicles was repeated.

- The patients were asked to complete both questionnaires again (see above).

- Laboratory values were determined (PSA, total testosterone)

The results of the questionnaires, the laboratory tests, and the ultrasound scan were coded as statistically analyzable parameters and the preinterventional data was compared to the postinterventional data and evaluated. The data are provided as average \pm standard deviation, as median and range (patient age) or as median and interquartile range (IPSS and QOL). Normal distribution of the data was checked via the D'Agostino-Pearson-Omnibus test. Normally distributed data were evaluated via paired t-test. Not normally distributed data and the results of the IPSS and QOL questionnaires were evaluated with the Wilcoxon signed rank test. A p-value < 0.05 was considered statistically significant. 


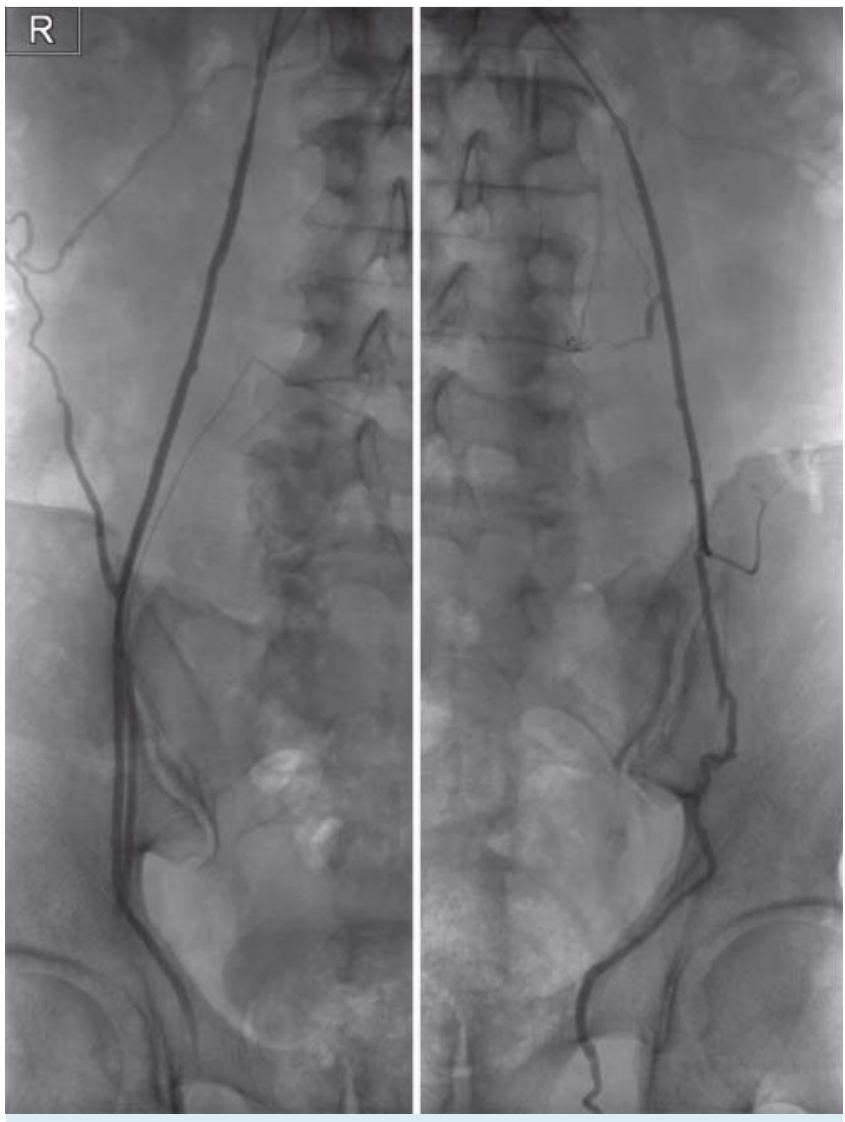

Fig. 1 Right and left spermatic vein after contrast medium injection.

\section{Results}

$\nabla$

The age of all treated patients at the time of the intervention was between 46 and 77 years (median 62), and the age of the 16 patients available for follow-up was between 51 and 77 years (median 66.5). All patients had had urologically diagnosed and symptomatic BPH for at least two years that could no longer be sufficiently treated with medication (in 23 patients) or for which treatment with medication had been rejected by the patient ( 7 patients). All patients were under regular urological monitoring, a clinically significant prostate carcinoma had already been ruled out in all patients by the treating urologists, a biopsy of the prostate was performed in 7 of the 30 patients for clarification. Testicular maldescent was seen in one patient. Occlusion or urological ligation of the spermatic veins had not been previously performed in any of the patients. Technically sufficient occlusion was possible in all patients on both sides.

Two injections of the polidocanol/air mixture per side were necessary in 20/30 patients and three injections were needed in 10/30 patients to reach the main vein as well as the additional collaterals. A metal coil was additionally inserted on both sides at the level of the iliac crest in $23 / 30$ patients with a solitary large-lumen spermatic vein on each side. A double inferior vena cava in two patients ( $\bullet$ Fig. 2a, b) and a circumaortic renal vein in another patient ( $\bullet$ Fig. $2 c$ ) were seen as interventionally relevant secondary findings. The intervention time was $89.5 \pm 25.8 \mathrm{~min}$., the fluoroscopy time was $31.3 \pm 15.4 \mathrm{~min}$. and the dose was 66.252 $\pm 54.745 \mathrm{mGy} / \mathrm{cm}^{2}$. During injection of the local anesthetic, one patient had a mild vasovagal reaction, and a second patient reported mild swelling in the region of the right spermatic cord for 24 hours after the intervention that resolved spontaneously and without consequences. A third patient experienced mild flank pain radiating into the groin after the intervention that also resolved without consequences after 2 days.

Follow-up data from at least 6 months was available for 16 of the 30 treated patients by the cut-off date. Evaluation of the questionnaires after 6 months showed a clear subjective improvement in symptoms. The IPSS (median 18 [interquartile range 20.75 - 14.50] vs. 9 [IQR $11.00-7.25$ ], p < 0.0001 ) was significantly lower 6 months after the intervention. In one patient with initially mild symptoms, the IPSS remained unchanged in the 6-month follow-up ( $\bullet$ Fig.3). The QOL score (median 4 [interquartile range 5-3] vs. 2 [IQR 3-1], $\mathrm{p}<0.001$ ) was also significantly lower 6 months after the intervention ( $\bullet$ Fig.4). However, the improved scores did not have a clear correlate in the prostate volume measurement that was not significantly changed with $54.31 \pm 30.90$ vs. $50.50 \pm 29.26 \mathrm{ml}$ ( $\mathrm{p}=\mathrm{n}$. s. $)$.

4 of 16 patients had a measurable post-void urine volume. The post-void urine volume remain unchanged 6 months after the intervention in 2 of these patients, decreased in one patient, and was no longer detectable in one patient. An improvement in the QOL and IPSS was nonetheless seen in these 4 patients. However, they still had the feeling of not being able to fully empty the bladder 6 months after the intervention. A varicocele was diagnosed sonographically in 4 of the 16 patients prior to the intervention but was no longer able to be detected after 6 months. A trabeculated bladder was diagnosed in only one patient and sufficient determination of residual urine was not possible in one further patient with bladder diverticulum.

No significant differences in both the peripheral total testosterone values $(4.55 \pm 1.27$ vs. $3.93 \pm 1.00 \mathrm{ng} / \mathrm{ml} ; \mathrm{p}=\mathrm{n}$. s. $)$ and the PSA values $(3.74 \pm 2.83$ vs. $4.06 \pm 3.34 \mathrm{ng} / \mathrm{ml} ; \mathrm{p}=\mathrm{n} . \mathrm{s}$. $)$ could be established in the 6-month follow-up.

\section{Discussion}

In 2008 Gat et al. formulated the hypothesis that insufficiency of the venous valves of the spermatic veins is a possible cause for the development of BPH [4]. The incidence of valve insufficiency and varicoceles increases with age and is approximately $75 \%$ in 70 -year-olds $[10,11]$. The hydrostatic pressure caused by a varicocele results in an increase in volume in the venous drainage system of the prostate and the excessively increased concentrations of free testosterone can promote prostate hyperplasia. As a result, it was able to be shown in venographic examinations that the blood column reaches a height of approx. $40 \mathrm{~cm}$ in the left spermatic vein and a height of approx. $35 \mathrm{~cm}$ in the right spermatic vein in the case of insufficient valves resulting in a hydrostatic pressure on the left of over $30 \mathrm{mmHg}$ and on the right of more than $27 \mathrm{mmHg}$ on the distal pampiniform plexus. Kim et al. concluded that both the height of the blood column and the number and cross-sectional area of the branches of the pampiniform plexus are responsible for the increased pressures [12]. This results, as explained by the Bernoulli equation, in increased static pressure in the 


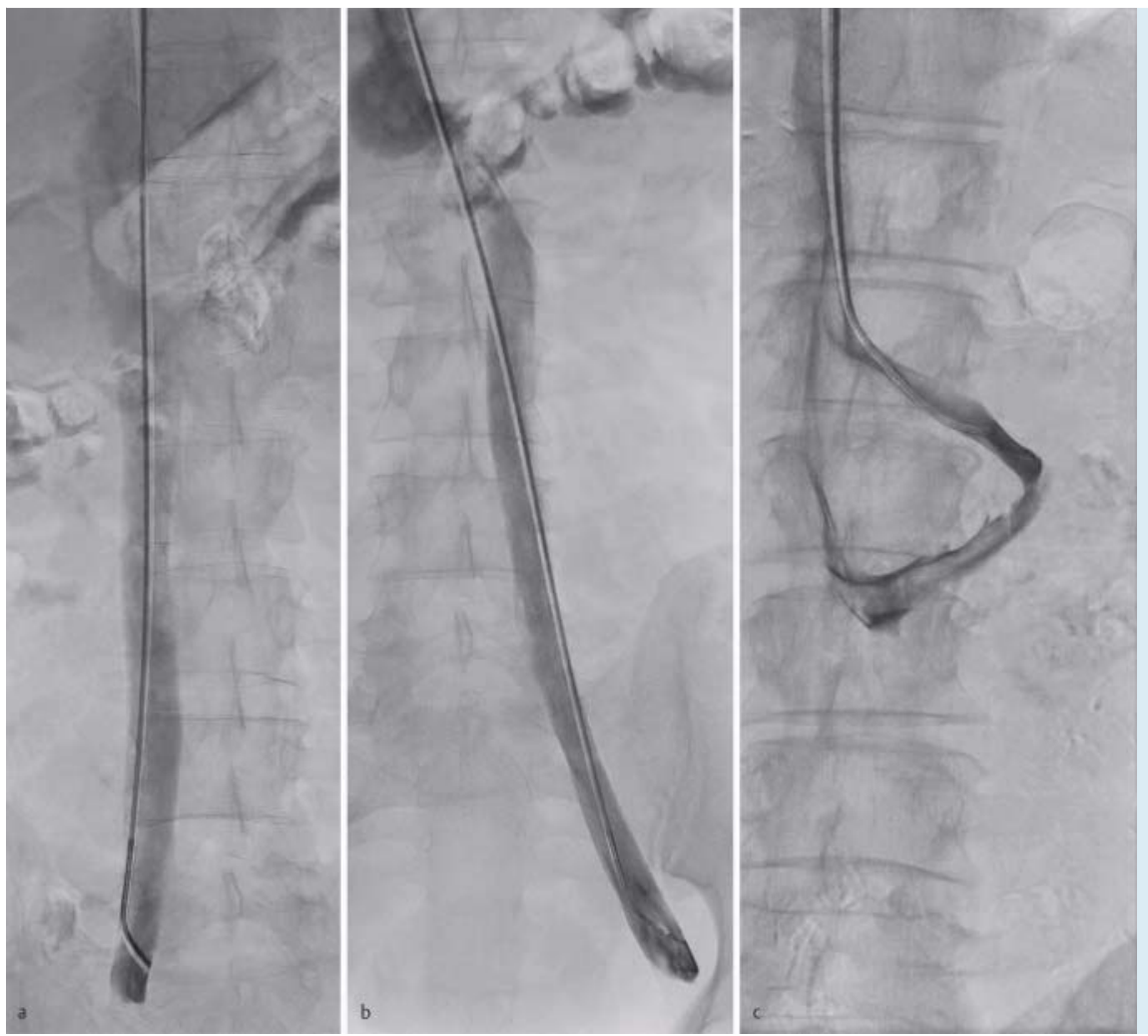

Fig. 2 Relevant anatomic variations. Double inferior vena cava with catheter in right $\mathbf{a}$ and left $\mathbf{b}$ portion. Circumaortic renal vein $\mathbf{c}$.

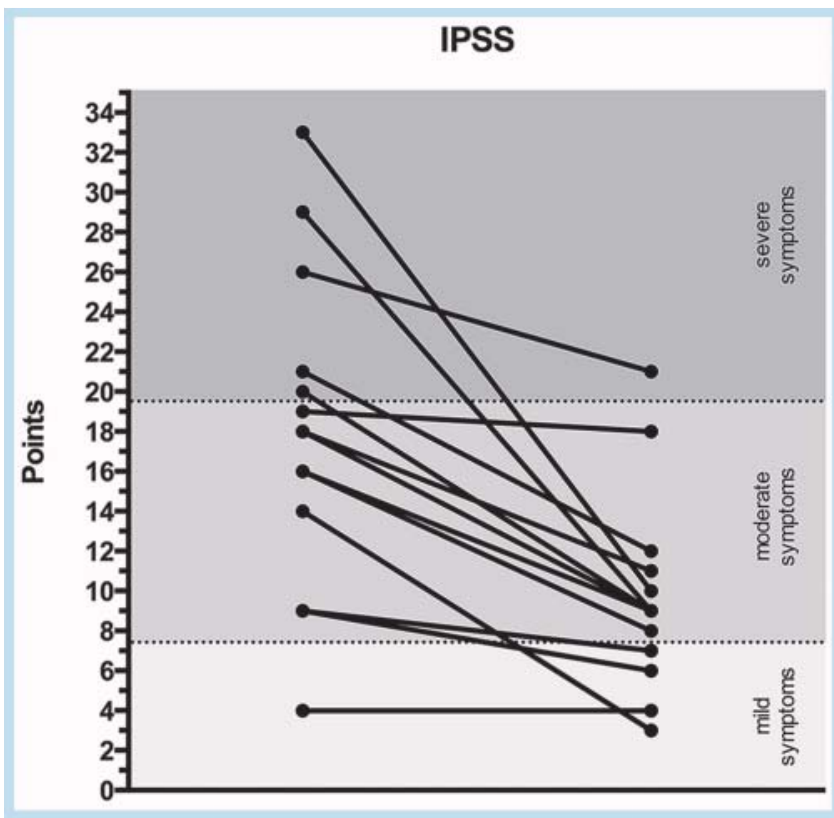

Fig. 3 IPSS before and 6 months after intervention.

pampiniform plexus with simultaneously slower flow rates, with the pressure increasing as the number of branches and thus the cross-sectional area of the pampiniform plexus increase. In addition, a relaxing effect of testosterone on varicoceles could be shown in in-vitro studies so that an additional increase in the cross section of the pampiniform plexus caused by vasodilation can be assumed $[13,14]$. Venous drainage of the testicles then primarily occurs via the vein of the ductus deferens. This vein that transports blood

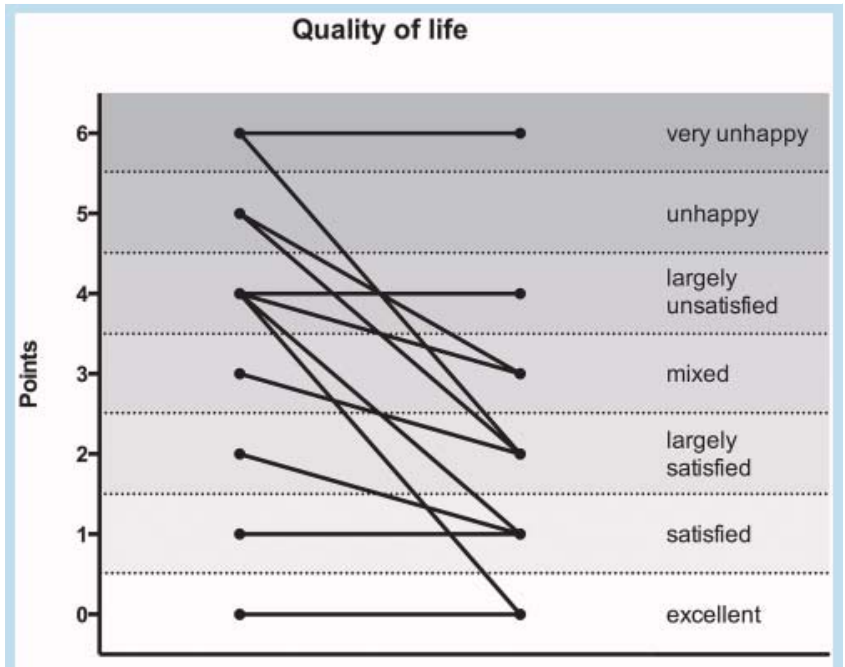

Fig.4 Quality of life score before and 6 months after intervention.

from the testicle drains via the vesicular vein into the internal iliac vein after joining with the prostatic venous plexus (Santorini). The vesicular vein represents the shared draining vessel for the testicles and prostate. Due to the significantly increased hydrostatic pressure in the veins coming from the testicle, the testosterone-rich blood of the testicle is then forced into the prostatic venous plexus in a retrograde manner ( $\bullet$ Fig. 5 ). The connection between the vein of the ductus deferens and the prostate could be shown in experiments on four-legged animals on the basis of an increase in the intraabdominal pressure since the spermatic veins are horizontal in this case and do not have any valves 


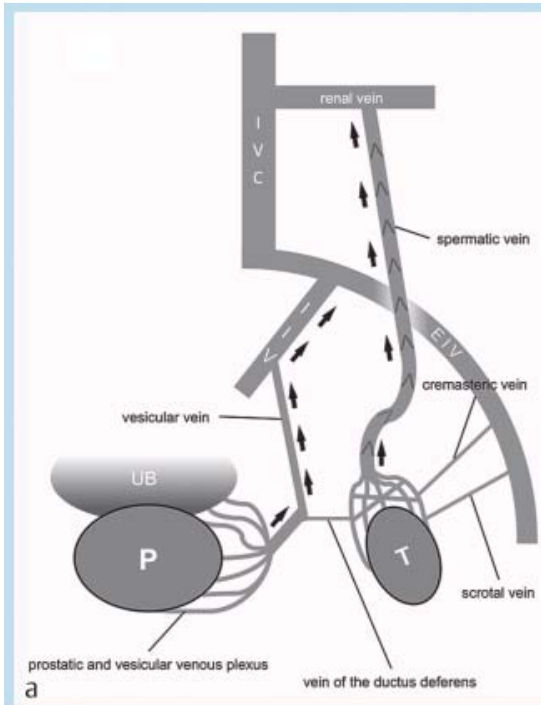

Fig. 5 Simplified diagram of the male urogenital veins. Only left side is shown. Arrows indicate main blood flow direction. a Normal with functioning spermatic vein valves. $\mathbf{b}$ Impaired spermatic vein valves with varicocele.

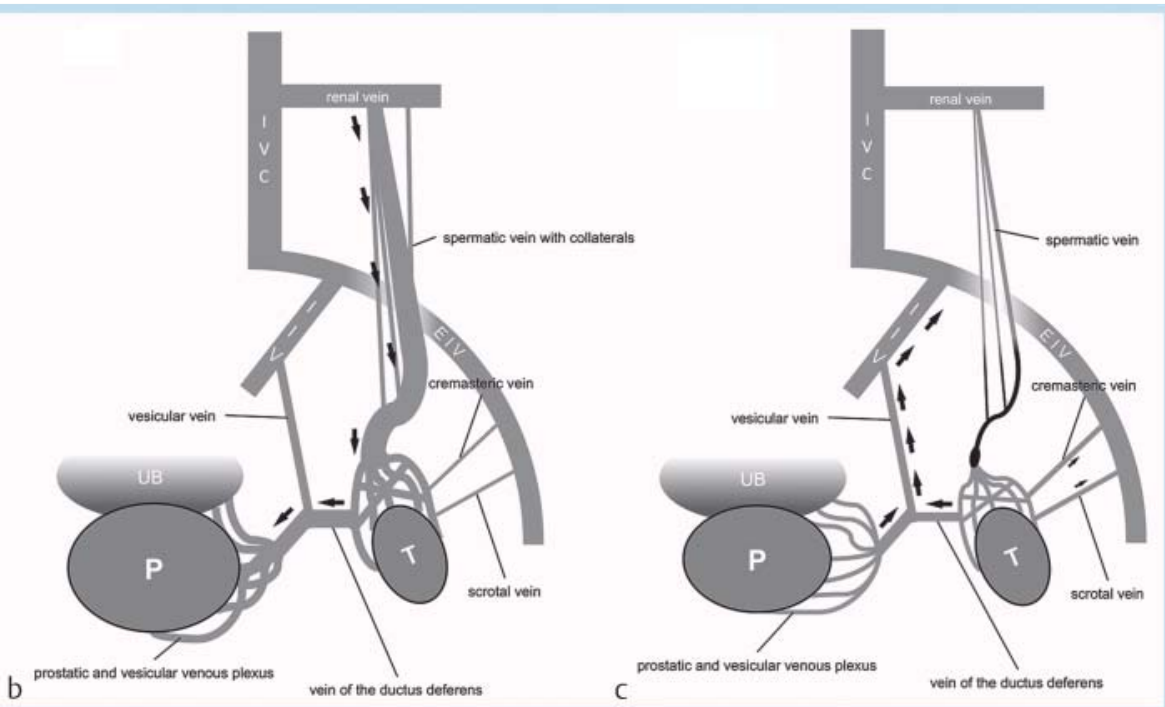

c After occlusion of the impaired spermatic vein and collaterals. P: prostate; $\mathrm{H}$ : testicle; HB: bladder; VCl: inferior vena cava; VIE: external iliac vein; VII: internal iliac vein.
$[15,16]$. Color Doppler ultrasound scans of infertile men showed dilation of the periprostatic veins with a significant retrograde flow and increased flow rates in the case of a varicocele on both sides [17].

Occlusion of the insufficient spermatic veins and their vertical collaterals should therefore lower the pathologically increased hydrostatic pressure. As a result, the blood flows out of both flow regions via the vesical vein. The testosterone-rich blood from the testicle thus also largely flows properly past the prostate into the vena cava so that when it reaches the prostate it is diluted 70-100 times [18] and bound to the sex hormone binding globulin (SHGB) ( Fig.5). Thus, only less than $2 \%$ of the total testosterone reaches the prostate as free testosterone [1]. As a result of the consequently normalized intraprostatic pressure and the decreased hormone load, the volume load and hyperplasia can be reversed. However, in the case of insufficient valves, the largely undiluted testosterone-rich blood reaches the prostate via the above-described shunt in a concentration that is up to 100 times higher.

A technically successful intervention without major complications was possible in all patients. In principle, the intervention is technically comparable with sclerotherapy of varicoceles via selective embolization of the spermatic vein in infertile young men so that similar undesired side effects and complications can be assumed ( $\bullet$ Table 1 ). In a study by Wunsch et al. including approx. 5,500 patients, the treatment is described as safe and efficient [9]. On the whole, the rate of possible complications from the occlusion of spermatic veins is significantly lower than in surgical therapy of $\mathrm{BPH}$. Consequently, complication rates of up to $20 \%$ are indicated for transurethral prostate resection (TURP) [19]. Spermatic vein should be occluded on both sides since insufficient veins occur on both sides in approximately $84 \%$ of patients, only on the left side in $14 \%$ and only on the right side in $2 \%$ [20]. As performed by us, the occlusion should be carried out slightly below the level of the iliac crest. There are smaller retroperitoneal collaterals above this point in approximately $75 \%$ of patients. These do not have valves and exert the same hydrostatic pressure since this does not depend on the vessel diameter but only on the height of the blood column [20].

The testicular veins that were able to be probed were dilated in all patients and a retrograde contrast medium flow was seen which was considered diagnostic for a varicocele. Interestingly, a varicocele could be detected sonographically in only 4/16 patients prior to intervention. Therefore, in a comparative study, only approximately $71 \%$ of varicoceles could be detected with unenhanced ultrasound and approximately $93 \%$ with Doppler ultrasound [21]. In addition, there are currently no valid criteria for the sonographic diagnosis of a varicocele [22].

The discrepancy between the subjective improvement in symptoms and the transabdominally determined insignificant change in prostate volume 6 months after the intervention was striking. An increased response of the periurethral zone to the expected androgen deprivation which can only be insufficiently detected by transabdominal ultrasound is given as a possible reason. Benign prostate hyperplasia occurs primarily in the periurethral and transition zones of the organ which can be attributed to an increased androgen receptor density in these regions. These zones include the cranial $2 / 3$ of the prostatic urethra from the bladder neck to the opening of the ejaculatory duct and result in flow or urination problems in the case of hyperplasia [23, 24]. Androgen deprivation via medication also results in a volume reduction preferably of the periurethral and transition zones [25, 26]. More extensive studies involving greater patient collectives with more precise volumetry of the prostate via transrectal ultrasound or magnetic resonance imaging (MRI) are necessary.

Major fluctuations in the PSA and total testosterone values were seen in the interindividual comparison and no significant changes were seen in the six-month follow-up. Since PSA is organ-specific but not disease-specific and can be falsified by inflammation, trauma or manipulation of the 
prostate, the determination of this value in the diagnosis of $\mathrm{BPH}$ and prostate carcinoma is still controversial [5].

Occlusion of the prostatic artery is another interventional method for treating BPH. A metaanalysis of nine studies showed a significant reduction of the IPSS from on average 23.31 to 11.92 , of the QOL from 4.34 to 2.4 and of the prostate volume from 83.6 to $66.4 \mathrm{ml}$ already one month after intervention [27]. The fast onset of action due to the induction of necrosis is accompanied by the - albeit minimal - risk of ischemia, in particular of the bladder wall (approx. $1 \%$ ) and the rectum (approx. $2.8 \%$ ). Our average intervention time in venous occlusion treatment is approximately $10 \%$ longer than the indicated intervention times for arterial embolization [27], which can be attributed to the difficult probing conditions of the testicular veins. The average fluoroscopy time for venous occlusion (31.3 min.) is slightly less than the times specified for arterial embolization (average of the averages $36.5 \mathrm{~min}$.) [28]. Moreover, additional dose-relevant imaging of the abdomen for visualizing the vessel anatomy is not necessary prior to venous occlusion [28].

The results of our study are limited by the currently low number of treated patients. Moreover, there are no results from long-term follow-ups.

In summary, venous occlusion treatment of BPH is an outpatient procedure with a low complication rate and satisfactory intermediate result. The long-term results and pathophysiological mechanisms of the method must be further evaluated.

Clinical Relevance of the Study

- Venous occlusion treatment of BPH is an outpatient procedure with a low complication rate.

- A satisfactory intermediate result was seen 6 months after occlusion.

- The medium and long-term results as well as the pathophysiological mechanisms of the method must be further evaluated.

\section{References}

1 Feldman BJ, Feldman D. The development of androgen-independent prostate cancer. Nature reviews 2001; 1 : $34-45$

2 Lagiou P, Mantzoros CS, Tzonou A et al. Serum steroids in relation to benign prostatic hyperplasia. Oncology 1997; 54: 497-501

3 Edwards JE, Moore RA. Finasteride in the treatment of clinical benign prostatic hyperplasia: a systematic review of randomised trials. BMC urology 2002; $2: 14$

4 Gat $Y$, Gornish M, Heiblum $M$ et al. Reversal of benign prostate hyperplasia by selective occlusion of impaired venous drainage in the male reproductive system: novel mechanism, new treatment. Andrologia 2008; 40: 273-281

5 Seitz M, Herlemann A, Magistro G et al. Diagnostik des benignen Prostatasyndroms. Der Urologe Ausg 2013; 52: 193 -196

6 Bittles MA, Hoffer EK. Gonadal vein embolization: treatment of varicocele and pelvic congestion syndrome. Seminars in interventional radiology 2008; 25: 261-270

7 Ansell G, Bettmann MA, Kaufman JA et al. Complications in Diagnostic Imaging and Interventional Radiology. 3. Aufl. Wiley-Blackwell: 1996
8 Caro IJ, Trindade E, McGregor M. The risks of death and of severe nonfatal reactions with high- vs low-osmolality contrast media: a meta-analysis. Ajr 1991; 156: 825-832

9 Wunsch R, Efinger K. The interventional therapy of varicoceles amongst children, adolescents and young men. European journal of radiology 2005; 53: 46-56

10 Canales BK, Zapzalka DM, Ercole CJ et al. Prevalence and effect of varicoceles in an elderly population. Urology 2005; 66: 627-631

11 Levinger $U$, Gornish M, Gat $Y$ et al. Is varicocele prevalence increasing with age? Andrologia 2007; 39: 77-80

12 Kim TB, Chang JH, Yoon SJ et al. Hydrodynamic relationship between color Doppler ultrasonography findings and the number of internal spermatic veins in varicoceles. Yonsei medical journal 2012; 53: $386-392$

13 Seyrek M, Irkilata HC, Vural IM et al. Testosterone relaxes human internal spermatic vein through potassium channel opening action. Urology 2011; 78: 233 e231 - e235

14 Irkilata HC, Yildiz O, Yildirim I et al. The vasodilator effect of testosterone on the human internal spermatic vein and its relation to varicocele grade. The Journal of urology 2008; 180: $772-776$

15 Pierrepoint CG, Davies P, Millington $D$ et al. Evidence that the deferential vein acts as a local transport system for androgen in the rat and the dog. Journal of reproduction and fertility 1975; 43: $293-303$

16 Dhabuwala CB, Roberts EE, Pierrepoint CG. The radiographic demonstration of the dynamic transfer of radio-opaque material from the differential vein to the prostate in the dog. Investigative urology 1978; 15: $346-347$

17 Sakamoto $H$, Ogawa $Y$. Is varicocele associated with underlying venous abnormalities? Varicocele and the prostatic venous plexus. The Journal of urology 2008; 180: 1427-1431

18 Jarow JP, Chen H, Rosner TW et al. Assessment of the androgen environment within the human testis: minimally invasive method to obtain intratesticular fluid. Journal of andrology 2001; 22: 640-645

19 Kacker R, Williams SB. Endourologic procedures for benign prostatic hyperplasia: review of indications and outcomes. Urology journal 2011; 8: 171-176

20 Gat Y, Gornish M, Belenky A et al. Elevation of serum testosterone and free testosterone after embolization of the internal spermatic vein for the treatment of varicocele in infertile men. Human reproduction (Oxford, England) 2004; 19: 2303-2306

21 Petros JA, Andriole GL, Middleton WD et al. Correlation of testicular color Doppler ultrasonography, physical examination and venography in the detection of left varicoceles in men with infertility. The Journal of urology 1991; 145: $785-788$

22 Lee J, Binsaleh S, Lo K et al. Varicoceles: the diagnostic dilemma. Journal of andrology 2008; 29: 143-146

23 Untergasser G, Madersbacher S, Berger P. Benign prostatic hyperplasia: age-related tissue-remodeling. Experimental gerontology 2005; 40: $121-128$

24 Monti S, Di Silverio F, Toscano $V$ et al. Androgen concentrations and their receptors in the periurethral region are higher than those of the subcapsular zone in benign prostatic hyperplasia (BPH). Journal of andrology 1998; 19: 428-433

25 Nishiyama T, Tomita Y, Takahashi K. Influence of androgen deprivation therapy on volume of anatomic zones of prostate in patients with prostate cancer using magnetic resonance imaging. Urology 2004; 63: 917-921

26 Feneley MR, Span PN, Schalken JA et al. A prospective randomized trial evaluating tissue effects of finasteride therapy in benign prostatic hyperplasia. Prostate cancer and prostatic diseases 1999; 2: 277-281

27 Schreuder SM, Scholtens AE, Reekers JA et al. The Role of Prostatic Arterial Embolization in Patients with Benign Prostatic Hyperplasia: A Systematic Review. Cardiovascular and interventional radiology 2014; DOI: 10.1007/s00270-014-0948-4

28 Pisco J, Campos Pinheiro L, Bilhim T et al. Prostatic arterial embolization for benign prostatic hyperplasia: short- and intermediate-term results. Radiology 2013; 266: 668-677 